\title{
A History of Neglect: Negotiating the Role of Safety in the Manhattan Project, 1939-1945
}

\section{Katherine Zwicker}

This paper examines the role of safety within the Manhattan Project, the Allied effort to build an atomic bomb during World War II. As an integral component of the American national defense strategy, the atomic bomb project was afforded tremendous resources and incorporated the expertise of the country's top scientists, engineers, government officials, and military personnel. As a result, considerable scientific and technological achievement was realized. The Manhattan Project marked an important point in the ascendancy of science and technology throughout the twentieth century. However, the largely political and military goals of the project had consequences. Insufficient knowledge was gained regarding radiation hazards as a result of a preoccupation with speedy and secretive nuclear weapons development and the difficulty scientists had conducting health-related research. This paper argues that safety concerns were secondary to speed and secrecy in the search for the world's first atomic bomb.

On 6 August 1945 the American bomber Enola Gay dropped Little Boy, the world's first uranium bomb, on the Japanese city of Hiroshima causing death and destruction of a magnitude never before seen, killing an estimated 210,000 people. ${ }^{2}$ A second weapon, a plutonium bomb referred to as Fat Man, was used to decimate the city of Nagasaki just three days later. The nuclear bombings in Japan helped bring an end to World War II in the Pacific arena and are pivotal points in the histories of Japan, the United States, global political relations, and modern warfare. As the culmination of the Manhattan Project-the Allied effort to build an atomic bomb - these bombings are also central to the history of that project. The creation of nuclear weapons, while a tremendous scientific, technological, and administrative feat, raised difficult and often subtle safety issues that were far less clearly defined than was the goal of building an atomic bomb. Insufficient knowledge of health and environmental hazards characterized all aspects of the Manhattan Project as there were numerous obstacles to obtaining information necessary to ensure safety and, I shall argue, too little priority granted to obtaining such information. The political climate of World War II ensured that project

\footnotetext{
'I wish to express my sincere thanks to Dr. Robert Smith who offered guidance throughout my research and the writing of this paper. I am also indebted to the Social Sciences and Humanities Research Council of Canada and the Smithsonian Institution. The former provided financial assistance and the latter provided interview transcripts which were instrumental to my research.

${ }^{2}$ Stephen I. Schwartz, ed., Atomic Audit: The Costs and Consequences of U.S. Nuclear Weapons Since 1940 (Washington, D.C. Brookings Institution Press, 1998), 396.
} 
leaders pressed the rapid and secretive development of nuclear weapons; indeed, in what scientists and engineers regarded as a race to build the bomb, speed and secrecy were of a much higher priority than was safety.

The issue of safety as it pertained to nuclear weapons development during the Manhattan Project is the central theme of this work. ${ }^{3}$ In regard to obtaining information about the health effects of radiation, scientists and physicians were at a huge disadvantage in that such research was largely impossible due to the ethical problem of using human subjects. The line between obtaining the necessary information for setting standards and ensuring safety was, as I will show, negotiated throughout the course of the project. Health physicists, charged by project leaders with the task of defining and preventing health hazards, derived safety standards from previous knowledge about $\mathrm{X}$-rays and radium and from animal experimentation conducted during the Manhattan Project. In his immediate post-war account of the Manhattan Project physicist Henry De Wolf Smyth naively reported that "As in all matters of health, the tolerance standards that were set and met were so rigid as to leave not the slightest probability of danger to the health of the community or operating personnel." Unfortunately, this was not the case. Such standards as "radiation tolerance doses" were constructions based on scientific research that even researchers at the time regarded as insufficient. It was not until the bombings in Japan that scientists were able to conduct the sort of research that they judged to be necessary for accurately defining radiation standards and determining the expected results of certain types of exposure; however, even then there was much uncertainty due to the lack of long-term monitoring.

Historian Barton Hacker argues that the goals sought after by scientists at the Los Alamos Laboratory in New Mexico were ranked in a hierarchy of importance. Building the bomb was of the utmost importance and secrecy, employed to maintain security, ranked second in importance. Safety was a concern, but it was willingly compromised to make the bomb and ensure secrecy. ${ }^{6}$ Quite in contrast to Smyth's above mentioned appraisal of safety, Hacker's

\footnotetext{
${ }^{3}$ Other aspects of the Manhattan Project, such as the roles of gender and race, have yet to be examined in the literature. I will not address these themes in my work but acknowledge that they are important in the history of the Manhattan Project. The role of gender, especially, could be explored in relation to the various historical actors involved in the project. Indeed, the scientists and top government, military, and industrial officials were all male. Women's involvement extended little beyond subordinate roles.

${ }^{4}$ Henry De Wolf Smyth, A General Account of the Development of Methods of Using Atomic Energy For Military Purposes Under the Auspices of the United States Government, 19401945 (Washington, D.C.: United States Govemment Printing Office, 1945), 87.

${ }^{5}$ See M. Susan Lindee, Suffering Made Real: American Science and the Survivors at Hiroshima (Chicago, IL: University of Chicago Press, 1994).

${ }^{6}$ Barton C. Hacker, The Dragon's Tail: Radiation Safety in the Manhattan Project, 19421946 (Berkeley, CA: University of California Press, 1987), 84.
} 
assessment of safety at Los Alamos leading up to the Trinity test is that "Safety never commanded topmost concern....Getting the job done came first." It seems that top Manhattan Project officials never considered safety hazards in direct conjunction with other risks, such as the possibility that the Germans might build the bomb first or that the project may suffer a breakdown in secrecy. I believe, however, that the hierarchy of risks Hacker suggests existed at Los Alamos characterized all aspects of the Manhattan Project.

It has only been in the last two decades that historians have been able to conduct a thorough analysis of radiation safety during the Manhattan Project. Prior to the mid-1980s most information pertaining to health and environmental issues remained classified. The historical works produced in the immediate postwar period and the few decades that followed were therefore largely administrative and technical histories. ${ }^{8}$ Hacker's 1987 book, The Dragon's Tail: Radiation Safety in the Manhattan Project, 1942-1946, was the first book to address the issue of safety in the Manhattan Project and remains the most comprehensive work of its kind. ${ }^{9}$ His discussion of the development of radiation safety in the context of the prevailing political climate and the advancement of science and technology marked a significant shift in the historiography. Other authors who shared Hacker's interest in radiation safety benefited greatly from a flurry of activity in the mid-1980s focused on the declassification of formerly secret information. Allen B. Benson's account of radiation releases at the Hanford plutonium production facilities in Washington State, for instance, was published shortly after the declassification of thousands of pages of information regarding Hanford operations. ${ }^{10}$ These documents were released at the request of the

\footnotetext{
${ }^{7}$ Ibid., 84.

${ }^{8}$ Physicist Henry De Wolf Smyth wrote the first official account of the atomic bomb project. Published just days after the bombs were dropped in Japan, his account was intended to inform the public of the Manhattan Project's history so as to illuminate the possibilities that existed for both military and civilian uses of atomic energy. Works that followed such as Richard G. Hewlett's and Oscar E. Anderson, Jr.'s history of the Atomic Energy Commission published in 1962 and Richard Rhode's 1986 account of the Manhattan Project fleshed out the story told originally by Smyth. However, like Smyth, Hewlett and Anderson and Rhodes offer minimal insight on the issue of safety. In 1990 Robert Seidel published a review essay discussing an array of books on the bomb which, cumulatively, help to fill out the literature on the atomic bomb project and the Cold War nuclear weapons complex. See Smyth; Richard G. Hewlett and Oscar E. Anderson, Jr., The New World: A History of the United States Atomic Energy Commission, Volume I: 1939-1946 (University Park, Penn.: Pennsylvania State University Press, 1962); Richard Rhodes, The Making of the Atomic Bomb (New York: Simon and Schuster, 1986); and Robert Seidel, "Books on the Bomb," Isis: Intemational Review Devoted to the History of Science and its Cultural Influences 81 (1990), 519-537.

${ }^{9}$ Hacker.

${ }^{10}$ Allen B. Benson, Hanford Radioactive Fallout: Hanford's Radioactive Iodine-131 Releases, 1944-1956 (Cheney, WA: High Impact Press, 1989).
} 
Hanford Education Action League (HEAL), an organization formed in September 1984 with the intent of pressuring the government and Hanford bureaucracy to release information regarding past and present operations at the site. After HEAL filed formal requests in January 1986 under the Freedom of Information Act (FOIA) the Department of Energy (DOE) released 19,000 pages of environmental reports related to operations at Hanford between 1944 and 1985."

The documents released, however, were mostly summary reports. Individuals scoured these reports and compiled a list of the many sources referenced in the summaries. Additional FOIA requests resulted in the declassification of a further 20,000 pages in April 1987. The battle to have more information declassified continued for many years and continues today. Between 1987 and 1993 more than 150 FOLA requests were filed by HEAL alone. Michele S. Gerber's On the Home Front: The Cold War Legacy of the Hanford Nuclear Site, a standard work on the history of Hanford published in 1992, reflects the growth of this grassroots involvement in the nuclear weapons complex which materialized alongside and in reaction to President Reagan's arms build-up throughout the 1980 s. $^{12}$

Although millions of pages of Hanford documents have now been released, a founding member of HEAL and Spokane resident, James P. Thomas, points out that "Relatively few pertain to how Hanford managers considered the protection of health and safety in making decisions about when to process plutonium. The result is that the public has learned a great deal about what happened at Hanford but not about how or why." 13 It is my aim to make a contribution to this very issue by illustrating how a preoccupation with rapid and secretive nuclear weapons development which characterized the Manhattan Project from start to finish overshadowed the importance of increasing knowledge of radiation hazards and ensuring worker safety. In this paper I will focus mostly on the pre-industrial phase of the atomic bomb project so as to illuminate how attitudes toward safety were established. I will argue that the only measure by which project leaders could conceive of the project's success was by creating the world's first atomic bombs. No expense was spared to achieve this goal. Overall, the project cost just shy of $\$ 2$ billion dollars $(\$ 1,889,604,000)$, which is the equivalent of nearly $\$ 22$ billion in constant 1996 dollars $(\$ 21,570,821,000) .{ }^{14}$ For

\footnotetext{
${ }^{11}$ Russell J. Dalton, et al., Critical Masses: Citizens, Nuclear Weapons Production, and Environmental Destruction in the United States and Russia (Cambridge, Mass.: The MIT Press, 1999), 37-38.

${ }_{12}$ Michele S. Gerber, On the Home Front: The Cold War Legacy of the Hanford Nuclear Site (Lincoln, NB: University of Nebraska Press, 1992).

${ }^{13}$ James P. Thomas, "I50 Requests," Bulletin of the Atomic Scientists vol. 56, no. 6

(November/December 2000), 41.

${ }^{14}$ The Brookings Institution, "U.S. Nuclear Weapons Cost Study Project," 2002

$<$ http://www.brook.edu/fp/projects/nucwcost/manhattan.htm> (17 May 2005).
} 
a project of such magnitude, relatively little attention and resources were directed toward safety.

\section{The Manhattan Project in its Infancy}

A new department, the Manhattan Engineer District (MED), was created within the Army Corps of Engineers on 13 August 1942 specifically for the purpose of building an atomic bomb. However, the beginning of what would become known as the Manhattan Project may be marked by the start of United States government support for uranium research. Nuclear fission was first demonstrated in 1938 by Lise Meitner and Otto R. Frisch who were working in collaboration with Otto Hahn and Fritz Strassman of the Kaiser Wilhelm Institute for Chemistry in Berlin. In an effort not to fall behind their German colleagues American and émigré scientists conducted their own research which culminated in the demonstration of nuclear fission in 1939 by physicist Enrico Fermi and his colleagues at the Metallurgical Laboratory in Chicago. ${ }^{15}$ At this time American and émigré scientists already felt an air of competition regarding the development of nuclear physics-competition which was rooted in the political instability of the times.

A consideration of the political climate in which the Americans built nuclear weapons is integral to a discussion of safety practices within the Manhattan Project. The Americans' attitude toward the war and both its allies and enemies helped to shape the decision-making process within the project. Fear of the Germans was, arguably, the most significant and ever present concern that influenced decisions about the course of the atomic bomb project. That is, the Americans were most afraid that the Germans were pursuing nuclear research and that the Germans would produce an atomic bomb first. For instance, late in 1943 physicists Alvin M. Weinberg, Eugene P. Wigner, Arthur Compton, and Fermi overestimated the threat posed by the German bomb project, as they later conceded. It was not until the war was drawing to a close that the Americans realized the German bomb project was so rudimentary that it posed no threat to them at all. Reflecting upon American miscalculations about the development of nuclear weapons in Germany, Weinberg explained that "the mistake [Wigner] made was that he assumed that every person on the German project was a Eugene P. Wigner, and that was a serious mistake." ${ }^{\prime 6}$ Weinberg's remark suggests that

\footnotetext{
${ }^{15}$ For a discussion of nuclear physics throughout the first half of the twentieth century see Rhodes. Rhodes provides a detailed account of the major advances made in nuclear physics and the history of key scientists, many of whom fled Germany or elsewhere in continental Europe and congregated in the United States.

${ }^{16}$ Alvin M. Weinberg, "The Manhattan Project: Collection Division 2: Oak Ridge," interview by Stanley Goldberg, Smithsonian Videohistory Program (3 March 1987), session 4, 34. For a discussion on the German bomb project and the Americans' perception of it see Thomas Powers, Heisenberg's War: The Secret History of the German Bomb (New York:
} 
Americans overestimated the scientific talent within Germany. This, certainly, has been one reason considered for the much debated issue of why the Germans were not successful in constructing nuclear weapons. However, with the highly capable physicist Werner Heisenberg working on the German project, Wigner and others dismissed this argument. ${ }^{17}$

Regardless of why nuclear weapons development was not successfully pursued in Germany, the issue important to safety practices in the American project was that the Americans perceived themselves as being caught in a frantic race with an enemy nation. A number of key scientists working on the American bounb project had resided in Germany while studying or teaching at the Kaiser Wilhelm Institute in Berlin and knew the capabilities of German scientists. Furthermore, they feared the power of the Nazi regime from which they had fled. They expressed their fears to American government and military officials, and, as tensions escalated in Europe on the eve of World War II, both responded. ${ }^{18}$ From the start, the American bomb project was rushed along in an attempt to defeat the Germans.

\section{The Metallurgical Laboratory and its Health Division}

The Metallurgical Laboratory, or Met Lab as it was commonly known, was instrumental in the Manhattan Project, especially during the early years prior to large-scale industrial involvement. Organized at the University of Chicago early in 1942, the Met Lab was designated as the main site of the Metallurgical Project-the project organized to develop the plutonium bomb. The Met Lab was comprised of four divisions: Chemistry, Engineering, Physics, and Health. The first three divisions were united in their goal to build a nuclear reactor, also

Alfred A. Knopf, 1993); and Mark Walker, Nazi Science: Myth, Truth, and the German Atomic Bomb (New York: Plenum Press, 1995).

${ }^{17}$ Alternatively, some argue that Hitler did not pursue nuclear research because he believed the Germans would win the war before the bomb could be built. See Wigner, interview by Goldberg, session 4, 33-34. Other interpretations of the failure of the German bomb project are discussed at length in Powers and Walker.

${ }^{18}$ President Franklin Delano Roosevelt created the Advisory Committee on Uranium in 1939. This partnership between the government and scientific community would later incorporate the military and the industrial sector as it evolved into the Manhattan Project. The Advisory Committee was superseded by the National Defense Research Committee (NDRC) in June 1940 which directed both the government's and scientific community's attention to national defense. In June 1941 the Office of Scientific Research and Development (OSRD) was created as an executive agency to oversee the NDRC. See Stanley Goldberg, "Inventing a Climate of Opinion: Vannevar Bush and the Decision to Build the Bomb," in The Scientific Enterprise in America: Readings from Isis, comp. and ed. Ronald R. Numbers and Charles E. Rosenberg (Chicago, IL: University of Chicago Press, 1996), 274. See also James G. Hershberg, James B. Conant: Harvard to Hiroshima and the making of the Nuclear Age (Stanford, CA: Stanford University Press, 1993), 127; and Hewlett and Anderson, 24 \& 41. 
referred to as a pile. ${ }^{19}$ In preparing to build the first pile a few conflicts arose, the adopted solutions to which underlined the urgency that characterized the bomb project. For instance, when a dispute arose regarding the size of the first pile to be built, Brigadier General Leslie R. Groves, who was placed in charge of the entire project in 1942, settled the dispute by voicing the opinion that speed was the most important factor and that money was no object. As historians Richard G. Hewlett and Oscar E. Anderson, Jr. have described, "Groves launched into the speech which was to become his trademark. He wanted speed. A wrong decision that brought quick results was better than no decision at all. If there were a choice between two methods, one of which was good and the other promising, build both. Time was more important than money, and it took time to build plants." ${ }^{20}$ Groves' preoccupation with building an atomic bomb in a timely matter, no matter what the cost, was a product of the time. The war infused a new sense of urgency into nuclear weapons research and development. With Groves' preference for speed in mind, the scientists compromised and decided to build more than one pile.

While the disagreement over the size of the first pile illuminates how, at the highest levels of the project, speed was of the utmost importance, the decision to build the pile on the University of Chicago campus reveals still more about attitudes toward safety. Originally plans called for the pile to be constructed at the Argonne Forest site outside of the city. The necessary materials for the pile were ready before the building at Argonne was complete so Fermi and Compton decided to build the pile in Chicago rather than delay. Both scientists and those with whom they consulted worried slightly about the safety hazards this posed. Compton contemplated asking permission from the University of Chicago President before going ahead with this project, which, as he later wrote in his account of the Manhattan Project, would have been the responsible thing to do. Ultimately, he decided not to do so, explaining that "Based on considerations of the University's welfare the only answer [the University President] could have given would have been no. And this answer would have been wrong."21 Compton considered himself to be a better judge of the dangers than the President of the University, which, arguably, he was. Yet, given the novelty of the enterprise as it existed in 1942, even he did not know the full range of hazards that could have resulted from building and operating a nuclear reactor. Nevertheless, Compton told Fermi to proceed with building the pile on a squash court under the west stands of the Stagg Athletic Field. Although neither James Conant, chemist

\footnotetext{
${ }^{19}$ A pile produces the materials needed to build plutonium bombs as it transforms uranium into plutonium. The structure of a nuclear pile consisted of grapbite blocks stacked to form a lattice that held uranium slugs. Uranium slugs were inserted into the front of the reactor and once irradiated, pushed out of the back of the reactor. The irradiated slugs underwent chemical separation to extract the plutonium from the slugs.

${ }^{20}$ Hewlett and Anderson, 181.

${ }^{21}$ Arthur Holly Compton, Atomic Quest: A Personal Narrative (New York: Oxford University Press, 1956), 138.
} 
and President of Harvard, nor Groves seemed pleased with the decision to build the pile on campus, they did not stop Fermi and Compton from pressing ahead. That Compton knew the University President would very likely disapprove of his actions and that Conant and Groves were hesitant to build the pile in such a heavily populated area is indicative of the fact that they were all aware that problems could arise and jeopardize the well-being of those working on the pile and those in the area surrounding the University campus. Since the project went ahead with no hesitation, however, it is clear that these safety concerns were not of the highest priority.

Despite the disregard shown to safety when planning to build the first pile, physicists did become increasingly worried about radiation safety when they judged a nuclear chain reaction was within reach. Early in 1942 physicists at the Met Lab employed one hematologist, Leon O. Jacobson, to establish a clinical screening process for project workers but decided that a research program on the biological effects of radiation was also in order. Accordingly, the Met Lab created the Health Division in the summer of 1942 and sought experts to staff this division. The Met Lab recruited biophysicist Dr. Kenneth S. Cole from the College of Physicians and Surgeons at New York. When he declined the position of director of the division it was then offered to and accepted by Dr. Robert S. Stone. Stone, from the University of California, had worked with Emest Lawrence at Berkeley on Lawrence's cyclotron project and medical research prior to the war. Drs. Simeon T. Cantril, a radiologist, and Ernest E. Wollan, who had trained under Compton, soon joined the project as well. With Stone as the director of the division, Cole, Cantril, and Wollan were chosen as chiefs of the biological research, medical, and health physics sections respectively. ${ }^{22}$ With this structure in place, each man recruited a small group of physicians and scientists, drawn from a network of those with whom they had made personal contact throughout their careers. ${ }^{23}$

Once staffed the Health Division was charged with the task of preventing serious injury of personnel due to work hazards, especially radiation-related injury. The two materials that posed the greatest threat to Manhattan Project workers were uranium and plutonium. ${ }^{24}$ The fission products created when

\footnotetext{
${ }^{22}$ Hacker, 29-31 and Compton, 177-178.

${ }^{23}$ The main players filling out the ranks of the Health Division were as follows: Jacobson, then working under Cantril in the medical section, was joined by physician James J.

Nickson; Wollan recruited radiological physicist, Herbert M. Parker, for his health physics section; and botanist, Raymond E. Zirkle, chemist, Richard Abrams, and biochemist, Waldo E. Cohn, were selected to join Cole's biological research group. A few more men were selected to fill positions within the lower levels of the division but this was its primary composition. See Hacker, 31 and Compton, 177-178.

${ }^{24}$ Uranium-238 is the isotope of uranium that is most abundant in nature. However, uranium-235, which accounts for less than $1 \%$ of the total metal in natural ores, and plutonium-239, which is derived from uranium, are the only two materials suitable to create
} 
uranium is split are extremely radioactive and they are released in large quantities throughout the separation process. ${ }^{25}$ Plutonium is created from uranium when uranium-238 is bombarded with neutrons. Using the technique then available, the conversion of uranium-238 into plutonium-239 took about two weeks at which time the plutonium was extracted from the uranium by chemical means. ${ }^{26}$ Relatively speaking the production of plutonium in a pile is a more straightforward process than is the separation of uranium isotopes. However, all of the by-products from plutonium production are highly radioactive. Manhattan Project scientists anticipated that several types of radiation hazards would result from both the separation of uranium isotopes and the production of plutonium. Uranium separation and plutonium production would generate neutrons as well as alpha particles, beta particles, and gamma rays. ${ }^{27}$ Very little detailed information about the health effects of these types of radiation was known. ${ }^{28}$

a rate of fission that can create an explosive chain reaction. These were not the only two materials which caused concem at the weapons laboratories. For instance, polonium, used to help initiate a plutonium chain reaction, was found to have similar properties as plutonium. It is an alpha emitter, but it was considered a lesser danger because it does not concentrate in bones and it is excreted from the body much more rapidly. See Hacker, 28 \& 63-64.

${ }^{25}$ Manhattan Project scientists pursued three types of isotopic separation in an attempt to devise the best method to produce uranium-235. They experimented with electromagnetic, gaseous-diffusion, and centrifugal separation processes. For more information on isotopic separation see Hewlett and Anderson, 91-103.

${ }^{26}$ For a more detailed discussion of the conversion of uranium-238 into plutonium-239 see Compton, 50-51.

${ }^{27}$ Various types of radiation - alpha, beta and gamma-are released when one element undergoes radioactive transformation to become another element, as is the case when uranium transforms into plutonium. Alpha and beta rays consist of high-speed particles that are relatively large in size as compared to other subatomic particles. Gamma rays are very similar to X-rays; they have great penetrating power and, thus, can affect most tissues in the body. Although alpha and beta rays do not easily penetrate matter, their size allows them to disrupt matter in close proximity and can be far more deadly than gamma rays. Alpha particles are particularly dangerous to humans if ingested or inhaled because they quickly bump into other particles changing the composition of those particles. Beta particles tend to damage the tissues close to the surface of the body. For more information on these various types of radiations see Leslie R. Groves, Now it Can be Told: The Story of the Manhatian Project (New York: Hasper \& Row, Publishers, 1962), 87 and Claudia Clark, Radium Girls: Women and Industrial Heath Reform, 1910-1935 (Chapel Hill, NC: University of North Carolina Press, 1997), 42.

${ }^{28}$ Early in 1943, at the start of the project to build a large-scale plutonium production plant, no scientist had a good understanding of the properties of plutonium because it had only recently been discovered. In 1944 the Met Lab acquired 11 milligrams of plutonium used for studies. It became apparent to those studying the material that the ingestion and inhalation of plutonium caused effects similar to that of radium ingestion and inhalation. Scientists discovered that plutonium is primarily an alpha-emitter. As such, it does not emit penetrating radiation but is extremely hazardous if ingested or inhaled because, like radium, 


\section{Instituting Safety Standards: The Problem of Uncertainty}

The Health Division focused its attention on two tasks: instituting safety standards and conducting research to learn more about health dangers. The members of the Health Division were well aware that they had much to learn about the biological effects of radiation. ${ }^{29}$ Of the limited information health physicists had about radiation, some was gathered from work done with X-rays. Wilhelm Conrad Röntgen had discovered X-rays in 1895. Scientists greeted this discovery with enthusiasm as they quickly saw that X-rays held great promise for diagnosing human diseases. The physicians and research scientists who employed $\mathrm{X}$-ray technology in the early decades of the twentieth century considered the side effects commonly noted-reddening of the skin and loss of hair-minor. Worse side effects, however, were occasionally noted as well; cancer, sterilization, and damage to blood-forming organs indicated that in addition to aiding medical research, $\mathrm{X}$-rays would also pose serious health risks. ${ }^{30}$ To mitigate the radiation hazards of X-rays the new health physicists of the post-World War I era sought to define a safe dose of X-rays that the human body could tolerate. ${ }^{31}$ Thus, when Manhattan Project scientists later attempted to set standards for all types of radiation to which workers may be exposed, X-ray and gamma ray standards already existed. ${ }^{32}$ Indeed, the United States Advisory Committee on X-ray and Radium Protection defined a safe radiation tolerance dose as 0.1 roentgens ( $r$ ) per day in 1936, a standard which the Metallurgical Project adopted in 1941. ${ }^{33}$

Tolerance was a complicated concept because, as the Health Division members knew, the effects of radiation doses on humans and other living systems depended upon various factors. The intensity of radiation, the number and frequency of exposures to radiation, and the duration of each exposure contributed to the overall biological effects of radiation. ${ }^{34}$ Furthermore, as historian Barton Hacker argues, radiation safety was defined in terms of observed damage. ${ }^{35}$ Thus, the Manhattan Project scientists' understanding of a tolerable dose of radiation was dependent only upon the resulting health effects that were visible to them. If effects went unnoticed they would not be considered in terms of defining a level

it concentrates in the bones and results in illnesses like cancer of the bone. See Smyth, 8889 and Hacker, 53 \& 62-63.

${ }^{29}$ Ibid., 29, 35, and 57.

${ }^{30}$ Ibid., 10; and Clark, 40-41.

31 Hacker, 14; and Robert S. Stone, "The Concept of a Maximum Permissible Exposure," Radiology: A Monthly Joumal Devoted to Clinical Radiology and Allied Sciences vol. 58, no. 5 (May 1952), 640.

${ }^{32}$ These standards, however, were not reliable. See Hacker, 38.

${ }^{33}$ The United States Advisory Committee's 1936 standard replaced its $0.2 \mathrm{r} /$ day tolerance dose which had been in effect since 1931. See Stone, 641 .

${ }^{34}$ Hacker, 18.

${ }^{35}$ Ibid., 19. 
of radiation that could be tolerated by the body. Stone delivered a lecture before the Radiological Society of North America in 1951 discussing this very matter. $\mathrm{He}$ lectured on the concept of a maximum permissible exposure to radiation ${ }^{36}$ stating that "one of the biggest problems we had to face in the Health Division of the Plutonium Project" was trying to determine to "what amount of ionizing radiation may a person be exposed without detectable damage to himself or future generations. ${ }^{, 37}$ Having defined the problem of radiation exposure in terms of "detectable damage" he emphasized the importance of both technology used to monitor exposure and knowledge of radiation effects.

Stone voiced the moral quandaries that physicians faced both during the war and after: "How are we to form a concept of a maximum permissible exposure in such a complex situation as this? Since any amount is deleterious, it is a question of how much damage we are willing to accept as 'permissible." 38 Unfortunately, the approach to radiation safety that considered any exposure as harnful did not triumph until a few years after the end of the war. The zeal of the Manhattan Project scientists and officials, driven by the pressures of war, shaped the concept of how much radiation could or could not be deemed permissible. Indeed, in an effort to produce the bomb as quickly as possible and by whatever means necessary Oak Ridge physicist A. H. Snell admitted that the scientists took some risks-safety was not their greatest concern. He commented on his own and his colleagues' mentality saying that "We figured the boys in the front were taking risks and that it was fitting for us to take a few also." 39 Radiation exposure was among the risks that scientists accepted-they deemed some exposure to be permissible.

Members of the Health Division gleaned other information about radiation hazards from the history of radium. In the early decades of the twentieth century radium, like X-rays, was employed for medicinal uses. The medicinal use of radium, however, resulted in many cases of radium poisoning, a condition that is now commonly linked to the history of dialpainters. Dialpainting-painting radium on watch faces to make them luminescent-began in $1917 .^{40}$ Even though

\footnotetext{
${ }^{36}$ The phrase "maximum permissible exposure" was introduced in the 1930 s to replace the concept of "tolerance dose" because physicians came to the conclusion that they could not be sure that any amount of radiation could be tolerated safely. "Tolerance dose" remained in use, though, well into the post-war period. See Stone, 639 .

${ }^{37}$ Ibid., 639.

${ }^{38} \mathrm{Ibid}, 656$.

${ }^{39}$ A. H. Snell, "Oak Ridge and U-235," interview by Joseph J. Ermenc (14 December 1967), in Atomic Bomb Scientists: Memoirs, 1939-1945: Interviews with Werner Karl Heisenberg, Paul Harteck, Lew Kowarski, Leslie R. Groves, Aristid von Grosse, and C. E. Larson, ed. Joseph J. Ermenc (Westport, CT: Meckler, 1989), 363. For a discussion of risks taken at Los Alamos and the scientists' attitude toward risk-taking see Hacker, 72-73.

${ }^{40}$ Approximately 2000 women were employed as dialpainters in the following decade and 4000 in total from 1917 through to the end of the 1940s. See Clark, 7-8.
} 
radium had been used for medicinal purposes since approximately 1910 , the dangers posed by radium were not yet known when the dialpainting industry began. ${ }^{41}$ It was only later discovered that radium has similar chemical properties to calcium and, thus, mostly concentrates in the bones rather than being excreted. Dialpainters primarily took radium into their bodies by inhaling radium dust and ingesting radium when pointing paintbrushes between their lips. In the 1920 s and 1930s dialpainters and former dialpainters started to develop various illnesses including cancer. Bone cancer and cancer of the nasal sinuses or mastoid cavities were especially common, but other forms of cancer occurred as well. Also, deaths resulted from illnesses other than cancer. For instance, some dialpainters died as a result of infections of dead bone and other tissues of the jaw-referred to as necrosis of the jaw-or from anemia. ${ }^{42}$

Health physicists could apply some information obtained from studying $\mathrm{X}$-rays and radium poisoning to their work on the Manhattan Project. Yet, neither the history of X-rays nor that of the dialpainters provided the Health Division with sufficient knowledge to determine safe standards for radiation exposure or to identify all hazards that workers faced. For instance, in 1944 health physicists set a provisional tolerance level of 5 micrograms for the amount of plutonium that could be safely retained in the body. Because the effects of plutonium and radium inhalation or ingestion were found to be similar, this plutonium tolerance level was derived from a pre-existing standard for radium. However, some differences well known to health physicists, such as the fact that plutonium is not as easily eliminated from the body as is radium, were not accounted for. One year later health physicists lowered the tolerance dose for plutonium to 1 microgram and even this standard remained "provisional." As is apparent here, uncertainty plagued the scientists as they tried to determine tolerance doses. ${ }^{43}$ Faced with such uncertainty Stone and other health physicists did display caution which earned him and the Health Division praise from their contemporaries. Smyth's immediate post-war assessment of the Health Division boasted of the Division's success. He explained that thanks to the Health Division and Stone's leadership "the hazards of the home and family car are far greater for the personnel than any dangers arising from the plant." 44 Likening radiation hazards to the home and car suggests a degree of familiarity which, during the course of the Manhattan Project, scientists could not claim to have.

\footnotetext{
${ }^{41}$ Some doubts about the safety of radium emerged during World War I. However, as scepticism of radium grew, some researchers and industrialists continued to promote the medicinal use of radium for altruistic reasons - to advance medicine-and for personal reasons - to profit from the development of new medicines and treatments. See Ibid., 58 \& 63-64.

${ }^{42}$ Ibid., 8.

${ }^{43}$ Hacker, 53-54 \& 62-63.

${ }^{44}$ Smyth, 108.
} 
Stone noted that with the achievement of a chain reaction on 2 December 1942 and the inevitability of a large-scale industrial project to build nuclear weapons research on the biological effects of radiation was conducted on a much larger scale than it had been previously. ${ }^{45}$ Health Division scientists, however, were very limited in the research they could pursue. Knowing that radiation was hazardous to human health, human radiation experimentation presented an ethical dilemma. ${ }^{46}$ Although the bulk of human experimentation took place from the late1940s through to the 1970s, the United States did conduct a few radiation experiments on humans during the war. From 1943 to 1944 a study at the University of Chicago exposed subjects to whole-body irradiation by X-rays and from 1943 to 1947 polonium injections were conducted at the University of Rochester. ${ }^{47}$ These experiments on humans were insufficient to answer the many questions that remained regarding the health effects of radiation. Frustrated by the inability to conduct human experimentation researchers in the medical section of the Health Division sometimes used themselves as guinea pigs. ${ }^{48}$

As an alternative to human experimentation, scientists conducted animal experimentation. For instance, in 1943 Donald R. Charles started radiation work with mice at the University of Rochester for the MED. ${ }^{49}$ The aim of his work was to determine the possible biological effects of frequent, low-level irradiation-the sort of exposure that MED personnel would likely endure. Arnold Grobman, a zoologist working on this genetics research, reported that based on their work with mice, a person exposed to supposedly safe levels of radiation ( $0.1 \mathrm{r} /$ day) for ten years would have a 1 in 94 chance of having a mutant child. This statistic shows a marked increase from the 1 in 667 chance of naturally occurring mutations. ${ }^{50}$ It is of little surprise, then, that Grobman reported all of these findings with

\footnotetext{
${ }^{45}$ Stone, 643.

${ }^{46}$ Use of human experimentation during the German atomic bomb project fuelled debate about the ethics of human experimentation in nuclear development which continued in the United States throughout the Cold War era. For a discussion of such debate see Gilbert Whittemore, "A Crystal Ball in the Shadows of Nuremberg and Hiroshima: The Ethical Debate Over Human Experimentation to Deveiop A Nuclear -Powered Bomber, 19461951," in Science, Technology and the Military, ed. Everett Mendelsohn, Merritt Roe Smith, and Peter Weingart (Boston, Mass.: Kluwer Academic Publishers, 1988).

${ }^{47}$ For a list of all human radiation experimentation conducted from 1943 to the 1970 s see Schwartz, 425-426.

${ }^{48}$ Hacker, 42 .

${ }^{49}$ The connection between Charles' work and the MED was kept secret to prevent suspicion about the activities of the MED. His experiment involved the use of male and female mice, caged in a ratio of 1 male to every 4 female. The male mice were exposed to radiation everyday but different groups of these mice were exposed to different levels of radiation. In general terms, the frequency and severity of mutations found among the offspring of these mice reflected the varying degrees of radiation. See Arnold B. Grobman, Our Atomic Heritage (Gainesville, FL: University of Florida Press, 1951), 53-56 \& 62-72.

${ }^{\text {so }}$ Ibid., 68.
} 
considerable pessimism. Indeed, the level of radiation considered tolerable or safe during the Manhattan Project could, according to such research, cause significant hereditary problems.

\section{The Industrial Stage: Negotiating and Emploving Safety Measures}

With the achievement of a chain reaction on 2 December 1942 at the Metallurgical Laboratory the Manhattan Project entered into an industrial stage; the project shifted its emphasis to producing the materials necessary to build an atomic bomb and to designing and building the bomb itself. At this time the scale of the Manhattan Project increased exponentially. Production sites of 54,000 acres in Tennessee and almost half a million acres in Washington state were chosen for the Oak Ridge and Hanford facilities respectively. ${ }^{51}$ Tens of thousands of workers were employed at the two sites-40,000 at Hanford alone. ${ }^{52}$ Construction and engineering for the Manhattan Project was contracted out, first, to the Stone and Webster Engineering Corporation in 1942, but when plans were made to plunge into large-scale plutonium production, E. I. du Pont de Nemours and Company was asked to step in.

During the industrial phase of the project different attitudes toward safety became increasingly apparent and the relationship that formed between science, the government, and the army was not always harmonious. The government officials and army personnel working on the Manhattan Project often had objectives different from those of the scientists. The former tended to invest more interest in applied scientific research or research aimed directly at obtaining a solution to a practical problem, whereas the latter favoured basic or fundamental research which has no such end in sight. ${ }^{53}$ When the Metallurgical Laboratory sought to conduct research on the biological effects of radiation it was evident that the scientists valued basic research to a greater extent than the army and government officials. Compton explained that he and his colleagues at the Metallurgical Laboratory deemed such research as highly important, not only for the safety of those working on various aspects of the Manhattan Project, but also for those who might be exposed to radiation in the future. ${ }^{54}$ General Groves did support such research, but, as Compton pointed out, "Before the appointment of General Groves there was some difficulty in convincing the Army that this

${ }^{51}$ Groves, $26 \& 76$.

${ }^{52}$ David A. Hounshell and John Kenly Smith, Jr., Science and Corporate Strategy: Du Pont $R \& D, 1902-1980$ (New York: Cambridge University Press, 1988), 339.

${ }^{\$ 3}$ Historians Lillian Hoddeson, Paul W. Henriksen, Roger A. Meade, and Catherine Westfall explained that it was only due to wartime circumstances that the scientists' "objectives shifted from understanding to use, and from general conceptions to particular materials and apparatuses." See Lillian Hoddeson, et al., Critical Assembly: A Technical History of Los Alamos during the Oppenheimer Years, 1943-1945 (New York: Cambridge University Press, 1993), 5.

${ }^{54}$ Compton, $178-179$. 
physiological work was of the importance implied by our rather extensive research program." ${ }^{, 55}$ This was because the army personnel involved in the atomic project, originally led by Colonel J. C. Marshall, prioritized research that directly contributed to the development and production of nuclear weapons. Although Groves did approve of the Metallurgical Laboratory's health-related research, he and other army personnel continued to give top priority to the production of weapons.

While many scientists believed army personnel were overly lax about safety most du Pont engineers made the same accusations about scientists. William P. McCue, a du Pont chemical engineer who first worked at the Argonne National Laboratory and then at Hanford, like other engineers, noted the scientists' apparent disregard for safety. He later recalled that compared to the engineers "the scientists were a little bit on the wild side." Argonne decided to extract some of the uranium from the reactor built at Argonne so that it could be sent to Oak Ridge. The task was planned to take one day with one team of men working in the morning and another in the afternoon so that no worker would receive too much radiation. McCue recalled that "At noon the job was not half done, so [the scientists] froze the first team in and said, "Okay, you work the rest of the day." 57 McCue, who disapproved of this decision, suggested that it was situations like this in which the du Pont personnel were more cautious of safety hazards than were the scientists. This incident also exemplifies how the concept of safe or permissible radiation exposure was negotiated in a particular context. Indeed, the Argonne scientists who planned the task of extracting uranium from the reactor incorporated what they thought was a safe level of radiation exposure--that which workers would receive over the course of half of a day's work - into their initial plans. However, when they realized that this job would take more than one day's work they increased the duration of what they considered safe radiation exposure - they adapted their concept of safety to the situation at hand. This particular situation was but a microcosm of the larger situation. Within the wartime environment, pressure to build an atomic bomb resulted in insufficient attention to safety hazards.

\section{Compartmentalization-A Hindrance to Safety}

One result of army control that interfered with the maintenance of safety was the compartmentalization policy which was employed to maintain the high level of secrecy of the project. Compartmentalization of work meant that each person was restricted from knowing any more information than was necessary to complete his or her job. Chemist John Googin provided an example of how

\footnotetext{
${ }^{55}$ lbid., 179.

${ }^{56}$ William P. McCue, "The Manhattan Project: Collection Division 1: Hanford," interview by Stanley Goldberg, Smithsonian Videohistory Program (13 January 1987), session 2, 9.

${ }^{57}$ Ibid., 9.
} 
extreme compartmentalization and secrecy could be; he recalled, "I had to write a report every week of the progress I was making, but when I finished writing it, I couldn't get it back because it was classified higher than I was allowed to have." 58 Googin's experiences and others like it generated frustration. As Albert Wattenberg, a spectroscopist, indicated, it is very possible that some information that should have been transmitted among various people was not. ${ }^{59}$ Physicist J. Robert Oppenheimer, director of the Los Alamos Laboratory, sought to increase the transmission of information; he challenged General Groves on the issue of compartmentalization. He wanted all of the workers at Los Alamos to be able to communicate with one another regarding any aspect of their work. Oppenheimer and Groves were able to reach an agreement allowing for the establishment of organizational meetings open to scientists to review progress being made at the laboratory. ${ }^{60}$

Other scientists also worried about the impact that compartmentalization had on the progress of the project. As physicist Lyle Borst suggested, "[compartmentalization] is absolutely antithetical to the scientists, because knowledge is power, and if you get compartmentalized, who is to say what information is required for that person to do his job?"61 Borst's point is very important, especially in regard to safety. Given that the scientists working for the Health Division knew very little about radiation dangers when the project started, they did not know what information would or would not be vital to their research. In the early days of bomb-building no one really knew this. Ideally, information would have flowed freely amongst people working in various areas of weapons development and production so as to raise awareness about potential hazards within all weapons facilities.

The workers' lack of knowledge was an obstacle to maintaining safety. Craft workers, labourers, and factory workers were given specific safety instructions that clearly implied danger. However, often they knew nothing of

\footnotetext{
${ }^{58}$ John M. Googin, "The Manhattan Project: Collection Division 2: Oak Ridge," interview by Stanley Goldberg, Smithsonian Videohistory Program (4 March 1987), session 6, 64.

${ }^{59}$ Albert Wattenberg, "The Manhattan Project: Collection Division 2: Oak Ridge," interview by Stanley Goldberg, Smithsonian Videohistory Program (3 March 1987), session 4, 79.

Conversely, some information was a little too accessible and fell into the hands of spies. For more information on atomic spies, such as Drs. Alan Nunn May and Klaus Fuchs see George O. Robinson, The Oak Ridge Story: The Saga of a People Who Share in History (Kingsport, TN: Southern Publishers, Inc., 1950), 74-75; Gregg Herken, The Winning Weapon: The Atomic Bomb in the Cold War, 1945-1950 (New York: Alfred A. Knopf, 1980), 129-137; and Gregg Herken, Brotherhood of the Bomb: The Tangled Lives and Loyalties of Robert Oppenheimer, Ernest Lawrence, and Edward Teller (New York: Henry Holt and Company, 2002), 83-102 \& 118-131.

${ }^{60}$ Hewlett and Anderson, 238-239.

${ }^{61}$ Lyle F. Borst, "The Manhattan Project: Collection Division 2: Oak Ridge," interview by Stanley Goldberg, Smithsonian Videohistory Program (3 March 1987), session 4, 75.
} 
radiation or the "special hazard," another term for radiation. ${ }^{62}$ If the supervising engineers deemed it necessary to provide operators with some information about radiation exposure it was explained in terms of the radiation produced from sun rays and X-rays. Workers were told to use the various detection machines within the facilities to determine if they had been exposed to radiation. ${ }^{63}$ Vivian Russell Chapman, a du Pont chemical engineer, argued that due to wartime conditions workers willingly upheld the secrecy of their jobs. He explained that "Everyone accepted [wartime secrecy]. This was a different climate and a different type of people than exist in this world today. There was a war going on. ${ }^{364}$ However, his observation that workers complied with strict measures of secrecy and compartmentalization may be rooted in the fact that most workers were oblivious to the hazards around them. Indeed, workers would likely not have been so passive about secrecy and compartmentalization if they knew that some information kept from them could be detrimental to their health. This is an issue not yet explored in the literature.

Unknowingly, workers had to rely upon senior scientists and engineers to ensure that they were not endangering themselves at work. Unfortunately, compartmentalization sometimes impeded senior employees from guaranteeing the safety of those who were less knowledgeable. For instance, Los Alamos physicist Hans Bethe recounted an incident following a visit made to Oak Ridge by his colleague Emilio Segré. Segré had returned to Los Alamos, the weapons design laboratory located in New Mexico, quite alanned by some of the processes being used at Oak Ridge to produce enriched U-235. Upon further investigation scientists deduced that due to the accumulation of uranium-235 throughout the enrichment process an explosive chain reaction could occur. This would have resulted in widespread radioactive contamination. ${ }^{65}$ This danger was identified by a scientist visiting the Oak Ridge facility, not one of the operators actually involved in uranium enrichment on a daily basis. Had the operators known more about their jobs, they could have identified this problem much earlier than Segré did. Fortunately, the problem was rectified, but the sequence of these events reveals how secrecy and compartmentalization jeopardized worker safety.

\section{Choosing Progress over Safety}

Safety problems were not only the result of unavoidable or difficult to overcome obstacles. Rather, they were also the direct consequence of decisions

\footnotetext{
${ }^{62}$ Hacker, 54.

${ }^{63}$ Vivian Russell Chapman, "The Manbattan Project: Collection Division 1: Hanford," interview by Stanley Goldberg, Smithsonian Videohistory Program (13 January 1987), session 2, 36 .

${ }^{64}$ Ibid., 38.

${ }^{65}$ Hans Bethe, Frederick Reines, Robert Christy, and J. Carson Mark, "The Manhattan Project: Collection Division 4: Los Alamos," interview by Stanley Goldberg, Smithsonian Videohistory Program (18 August 1989), session 14, 23-24.
} 
made by top project officials. As I have discussed elsewhere, ${ }^{66}$ such decisions as that made to begin experimental operations at the Oak Ridge plutonium pilot plant, to speed up plutonium production at Hanford, and to conduct the Trinity test in New Mexico under less than favourable weather conditions illustrate how the urgency of weapons production was of much greater importance to project leaders than safety. In each of these situations the possibility or even likelihood of radiation hazards was known but deemed to be less important than the overall goal of building an atomic bomb as quickly as possible. As a result, on-site workers and surrounding populations were exposed to high levels of radiation either through indirect, internal exposure or direct, external exposure. The former occurred when radioactive particles or gases contaminated the environment-the atmosphere, soil, groundwater, and/or rivers-and entered the food chain, whereas the latter involved direct contact with radioactive materials unmediated by environmental pathways. Many on-site workers and those in areas surrounding the Oak Ridge and the Hanford facilities developed various types of cancer and other illnesses. Studies started in the late 1980s and early 1990s, such as the Hanford Environmental Dose Reconstruction (HEDR) Program, the Hanford Thyroid Disease Study (HTDS), and the Clinch River Environmental Restoration Program, have tried to determine the link between radiation exposure in the Manhattan Project and health effects in the Oak Ridge and Hanford areas. ${ }^{67}$ These studies have yet to prove a strong relationship between radiation exposure and illness, but those living in the Hanford and Oak Ridge areas would confidently argue that radiation exposure was the reason for the high incidence of cancer and other illnesses. ${ }^{68}$

\footnotetext{
${ }^{66}$ See my Master of Arts project titled "Sacrificed for War: The Role of Safety in the Manhattan Project, 1939-1945," (University of Alberta, 2004).

${ }^{67}$ See Hanford Health Information Network, "The Release of Radioactive Materials from Hanford: 1944-1972," Spring 1997, $<$ http://www.doh.wa.gov/hanford/publications/history/release.html> (2 August 2004); Oak Ridge National Laboratory, "Clinch River Environmental Restoration Program," $<$ http://research.esd.ornl.gov/CRERP/> $\left({ }^{30}\right.$ August 2004 $)$; and Deward E. Walker, Jr. and Lawrence W. Pritchard, Estimated Radiation Doses to Yakima Tribal Fisherman: A Test Application of the Columbia River Dosimetry Model Developed for the Hanford Environmental Dose Reconstruction Project (Boulder, CO: Walker Researcb Group, Ltd., 1999).

${ }^{68}$ For personal accounts from Hanford downwinders regarding the results of such studies see Hanford Health Information Network, "The Release of Radioactive Materials from Hanford;" and D. F. Carter, "Life After Hanford," The Seattle Times, 9 February 1999 [newspaper on-line] $<$ http://seattletimes.nwsource.com/news/editorial/html98/down_020999.html > (30 August 2004).
} 


\section{Conclusions}

The Manhattan Project marks a truly remarkable period in the history of the United States as well as the history of science and technology. Understandably, many histories written about the Manhattan Project emphasize the sheer accomplishment of the project; the collaborative effort of the scientists, government officials, military personnel, and industrial contractors to build the world's first atomic bombs was unprecedented. Never before had these groups come together on such a scale in the attempt to attain a common goal. Nor had the United States ever embarked upon such a vast and costly project aimed at protecting national security.

At the beginning of the Manhattan Project American scientists and government officials had little knowledge or experience to build upon other than their newly acquired knowledge of uranium fission. Given the uncertainties of the global political climate that emerged at the beginning of World War II, the development of uranium fission provided ample reason for the United States to put forth a concerted effort to build an atomic boinb. Wartime conditions which influenced the decision to pursue the atomic bomb project continued to shape all aspects of the project once underway. That is, the Americans' fear that the Germans were building their own atomic bomb and that they would do so first evoked a great sense of urgency and secrecy within the Manhattan Project. In addition to the lack of information pertaining to radiation hazards, it was primarily these two characteristics of atomic bomb development-urgency and secrecythat hindered safety throughout the Manhattan Project.

Safety issues were not completely neglected and, certainly, a lot of progress in the field of radiation safety was made during the project. However, in what might be considered the United States' most risky and urgent experiment in the union of science, technology, govermment, and the military, safety concerns were not a top priority. Manhattan Project engineers, scientists, and officials channelled most of their energy into successfully building an atomic bomb and comparably less of an effort into ensuring the safety of workers and American citizens inhabiting the regions in which weapons production facilities were built.

Germany surrendered on 8 May 1945, prior to the first successful test of an atomic bomb, which occurred on 16 July 1945 at the Alamogordo Bombing Range in New Mexico. The United States was still fighting a war in the Pacific arena so it was there that the atomic bomb made its world-wide debut. The wartime pressures for rapid and secretive bomb development seemed to have lessened when the bombs were dropped on Japan and publicly revealed. Indeed, the Americans had won what they had perceived as a race to develop the atomic bomb and an element of the extreme secrecy that marked the project disappeared overnight. Although the context of nuclear weapons development and production changed when the war ended-the Manhattan Project was no longer secret and the United States was no longer engaged in a war with an enemy nation pursuing a nuclear weapons programme of their own-disregard toward safety still 
characterized nuclear weapons development. For instance, the United States embarked upon a series of weapons testing in the Marshall Islands and the Nevada test site in New Mexico and, as was the case during the Manhattan Project, safety was not a high priority. ${ }^{69}$ Post-war hostility between the United States and their former ally, the Soviet Union, prolonged the wartime pressures that had influenced attitudes toward safety. The Cold War fostered an arms race between the United States and the Soviet Union which, much like World War II, encouraged rapid and secretive weapons production. Indeed, built upon the foundation provided by the Manhattan Project, the United States continued on its path to becoming a national security state, producing the world's most powerful military-industrial complex or, more specifically, nuclear weapons complex.

Radiation safety was an important component of research and practise within the Manhattan Project; however, it was not a component that contributed directly to the creation of atomic bombs. Researching and preventing safety hazards were part of a project in which national security and military preparedness were always the ultimate goals. As such, health and environmental safety were jeopardized in favour of ensuring speedy and secretive development of the atomic bomb.

${ }^{69}$ See Jonathan M. Weisgall, Operation Crossroads: The Atomic Tests At Bikini (Annapolis, Md.: Naval Institute Press, 1994). 